\title{
Conversion of Waste Plastic into Solid Briquette in Combination with Biomass: Bangladesh Perspective
}

\author{
Mitun Chandra Bhoumick ${ }^{1}$, Niloy Chandra Sarker ${ }^{2}$, Md. Mahmudul Hasan ${ }^{3}$, Bishaw Kanti Roy ${ }^{4}$ \\ Lecturer, Department of Chemical Engineering \& Polymer Science, \\ Shahjalal University of Science \& Technology, Sylhet, Bangladesh ${ }^{1}$ \\ Assistant Professor, Department of Chemical Engineering \& Polymer Science, \\ Shahjalal University of Science \& Technology, Sylhet, Bangladesh ${ }^{2}$ \\ Undergraduate Student, Department of Chemical Engineering \& Polymer Science, \\ Shahjalal University of Science \& Technology, Sylhet, Bangladesh ${ }^{3,4}$
}

\begin{abstract}
Every year millions of tons of agricultural wastes are generated in the country. The percentage of Plastic waste is also increasing in the Municipal Solid Waste management system. These Biomasses or Agricultural wastes can be used as energy source directly. The problem is the energy efficiency and environmental pollution. Meanwhile waste plastics are recycled and a major portion of it goes to land filling. As plastics possess high fuel value, these can be combined with biomasses to prepare solid briquette. This current study looks to develop a good composition of Briquette which comprises of conventional Biomasses and Plastic waste. The total work is carried out in three segments; (i) Preparing a Lab grade Thermal Piston Press for Plastic-Biomass Briquette Manufacturing, (ii) Sample preparation with various proportion of Biomass and Waste Plastic, and (iii) Characterization of the prepared sample. From the study it is seen that the fuel value of Biomass Briquette increases with mixing of plastics, which minimizes water absorption and friability, increases storage capacity and strength. The characterization of Plastic-Biomass Briquette shows that with the addition of $10 \%$ waste plastic the calorific increases $40 \%$ by margin and doubles the compressive strength.
\end{abstract}

Keywords: Plastic Waste, Plastic-Biomass Briquette, Thermal Piston Press, Compressive strength.

\section{INTRODUCTION}

The development of a nation needs a persistent supply of This supply is quite insufficient compared to the energy resources. The problem of energy crisis is increasing demand of the energy. Again the government increasing day by day in the developing countries like energy policy has changed largely to encourage industrial Bangladesh. The reservoirs of conventional energy development promising natural gas supply ahead of resources as petroleum and natural gas have greatly domestic usage. According to the gas well production data reduced and the country is largely dependent on the import sheet total recoverable gas deposit is 20.4TCF, while so of fuel to meet their energy needs [1,4]. The use of far the used amount is $12.4 \mathrm{TCF}$ [1]. At this rate if the alternative fuel sources has been proposed from time to consumption carries on Bangladesh likely to experience time to overcome this issue. According to the Petrobangla energy scarcity by 2031. This threat of depletion has annual report 2014, $12 \%$ of the total gas production goes forced a change in the energy policy. The tariff has been to domestic purposes [1]

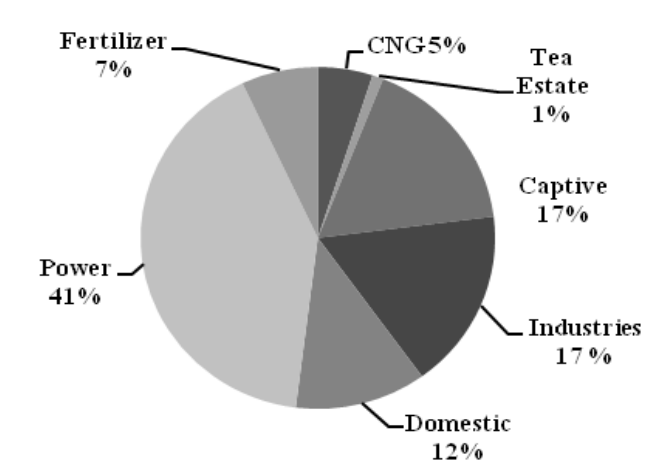

Figure 1: Natural Gas Distribution in Bangladesh. readjusted and use of Biomass and alternatives is encouraged.

\section{BACKGROUND}

Economic growth and changing consumption and production patterns are resulting into rapid increase in generation of waste plastics in the world [8]. The world's annual consumption of plastic materials has increased from around 5 million tons in the 1950 s to nearly 100 million tons; thus, 20 times more plastic is produced today than 50 years ago. This implies that on the one hand, more resources are being used to meet the increased demand of plastic, and on the other hand, more plastic waste is being generated. The scenario is not different in Bangladesh either. This is due to the effect of rapid urbanization. Over 
the last Decade Bangladesh has been doing well in associated with very low thermal efficiency and Manufacturing Plastic goods for both Domestic Use and widespread air pollution. The conversion efficiencies [10] Export. The Per capita use of plastic hence has increased are as low as $40 \%$ with particulate emissions in the flue and still going on strongly [9]. In consequence the percentage of MSW (Municipal Solid Waste) is experiencing increasing trend in the quantity of Waste Plastic. Due to the Increase in generation, waste plastics are becoming a major stream in solid waste. After food waste and paper waste, plastic waste is the major constitute of municipal and industrial waste in cities. Even the cities with low economic growth have started producing more plastic waste due to plastic packaging, plastic shopping bags, PET bottles and other goods/appliances using plastic as the major component. This increase has turned into a major challenge for local authorities, responsible for solid waste management and sanitation. Due to lack of integrated solid waste management, most of the plastic waste is neither collected properly nor disposed of in appropriate manner to avoid its negative impacts on environment and public health and waste plastics are causing littering and chocking of sewerage system [8, 9]. Plastics are not degradable therefore exposure to land filling supposed to have severe impact in Environment. Recycling and reusing is on the practice, while some fraction of the waste plastic is converted into liquid fuel, composite manufacturing and roadside construction works. Plastic waste can be used as a potentially cheap source of chemicals and energy.

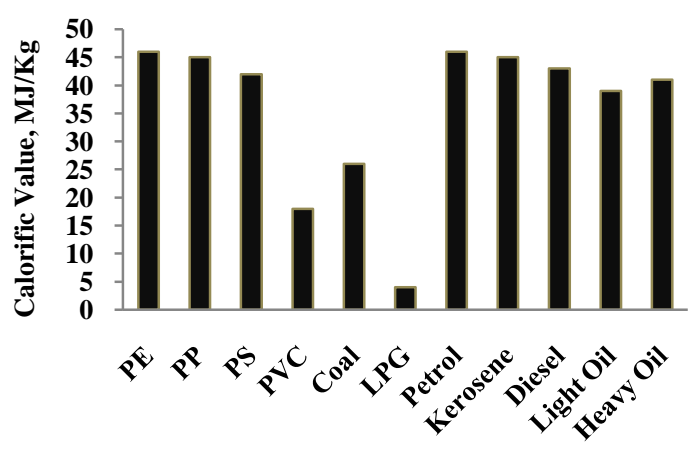
gases. In addition, a large percentage of unburnt carbonaceous ash has to be disposed of. In the case of rice husk, this amounts to more than $40 \%$ of the feed burnt. Briquetting of the husk could mitigate these pollution problems while at the same time making use of this important industrial/domestic energy resource.

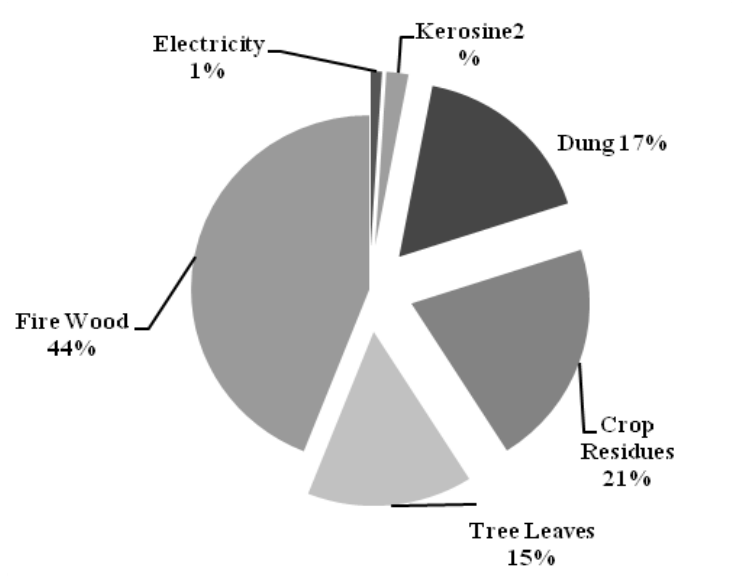

Figure 3: Rural Energy Sources in Bangladesh

The briquettes can be used for domestic purposes (cooking, heating, barbequing) and industrial purposes (agro-industries, food processing) in both rural and urban areas $[5,6]$. Thus Biomass briquetting is the densification of loose biomass material to produce compact solid composites of different sizes with the application of pressure. Briquetting of residues takes place with the application of pressure, heat and binding agent on the loose materials to produce the briquettes.

\section{III.METHODOLOGY}

\section{A. Raw Materials}

Semi dried saw dust was collected from the local Saw mills. The moisture content of the collected Saw Dust

Figure 2: Calorific Value of Some Plastic Material and Hydrocarbon fuel Sources.

The use of agricultural and agro-industrial waste as biomass fuel for power generation like briquettes [2, 3] can be an alternative solution to the problems related at their disposal. Briquettes produced from lignocellulosic waste, through a simple process and low cost are an excellent source of cheap energy and environmentally correct, in many cases, ideal for replacing fossil fuels in use today, with significant economic and environmental advantages [10]. Many of the developing countries produce huge quantities of agro residues but they are used inefficiently causing extensive pollution to the environment [11]. The major residues are rice husk, coffee husk, coir pith, jute sticks, bagasse, groundnut shells, mustard stalks and cotton stalks. Sawdust, a milling residue is also available in huge quantity. Apart from the problems of transportation, storage, and handling, the direct burning of loose biomass in conventional grates is and rice straw was also used for the briquetting purpose, which was collected from the local rice mills. These raw materials were sun dried and milled to obtain small particle size for better compaction. In this study the necessary waste plastic for briquetting was collected from sylhet city corporation MSW management plant. The targeted materials were LDPE, PE and PP.

\section{B. Instrumentation}

Biomass densification represents a set of technologies for the conversion of biomass residues into a convenient fuel. The technology is also known as briquetting or agglomeration. Depending on the types of equipment used [11], it could be categorized into five main types: - Piston press densification - Screw press densification - Roll press densification - Pelletizing - Low pressure or manual presses. Based on the requirement of the process a Lab grade Thermal Piston Press (TPP) was designed and fabricated for this study. The various components of the 
designed TPP are; Handle, Threaded rod, Movable cover (It gives the pressure on the product.), Rod holder, Metal cylindrical chamber, Insulation (Lower part of the metal cylinder is insulated so that heat cannot be lost to the atmosphere).Output channel: It's the channel from where product is collected. Concrete housing Electric heating coil (It is used for heating purpose).

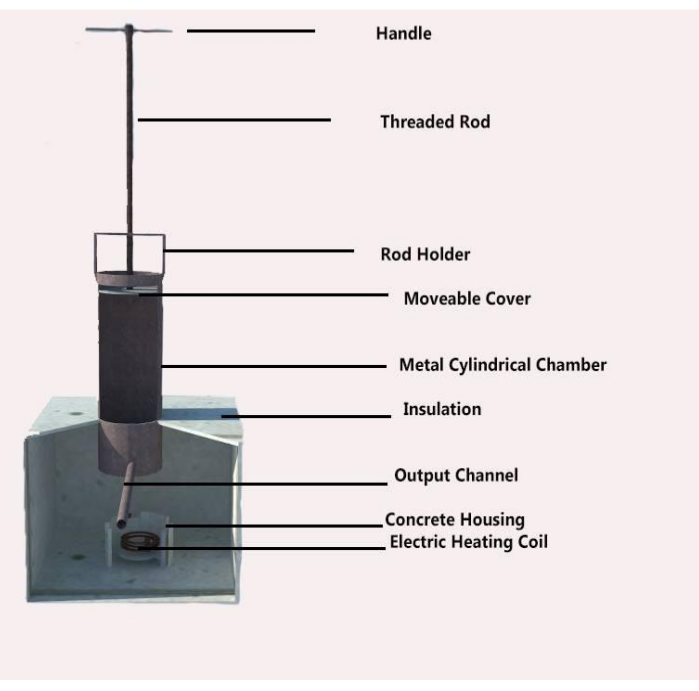

Figure 4: Schematic Diagram of a Thermal Piston Press Unit. Prepared for the Briquetting of Waste Plastic (WP) and Biomass.

\section{Preparation of Sample}

The sample manufacturing process is illustrated below. The temperature of the TPP was maintained among 120$170^{\circ} \mathrm{C}$. It took around 5-7 minutes to complete a batch.

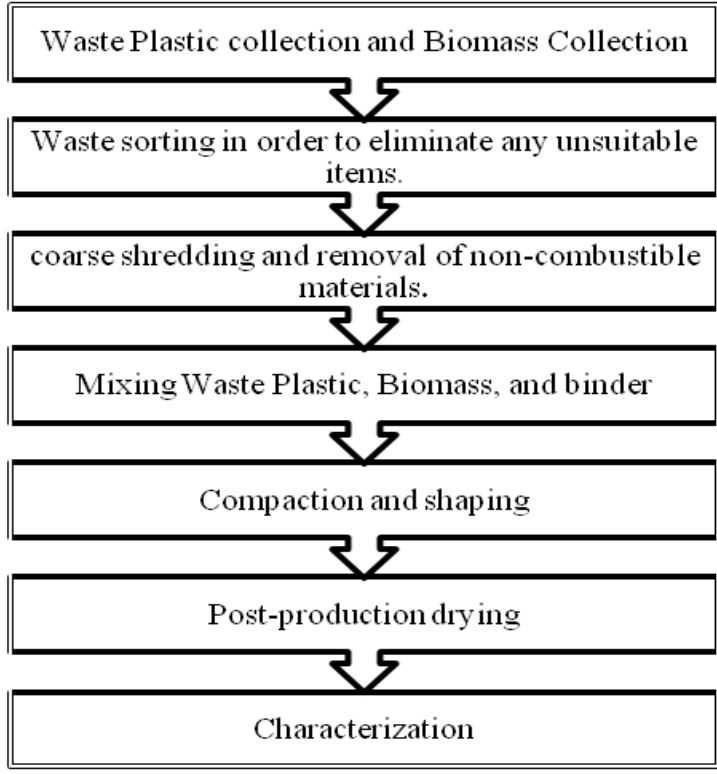

Figure 5: Flow Diagram of Waste Plastic-Biomass Briquette Manufacturing Process.

\section{Compaction Characteristics of Biomass and Their} Significance

In order to produce good quality briquettes, feed preparation is very important. Feed parameters, as these play a practicable role in briquetting technology [4]. For densification of biomass, it is important to know the feed parameters that influence the compaction process. For different briquetting machines, the required parameters of raw materials like their particle size, moisture content, and temperature are different. These are discussed below.

\section{i. Effect of moisture on Briquetting}

The percentage of moisture in the feed biomass is a very critical factor. In general, it has been found that when the feed moisture content is $8-10 \%$, the briquettes will have 6-8\% moisture. At this moisture content, the briquettes are strong and free of cracks and the briquetting process is smooth. But when the moisture content is more than $10 \%$, the briquettes are poor and weak and the briquetting operation is erratic. Excess steam is produced at higher moisture content leading to the blockage of incoming feed from the hopper, and sometimes it shoots out the briquettes from the die. Therefore, it is necessary to maintain optimum moisture content. In the briquetting process water also acts as a film type binder by strengthening the bonding in briquettes. In fact, the surface effects of water are so pronounced that the success or failure of the compaction process solely depends upon the moisture content of the material. The right amount of moisture develops self-bonding properties in lignocellulosic substances [5] at elevated temperatures and pressures prevalent in briquetting machines. It is important to establish the initial moisture content of the biomass feed so that the briquettes produced have moisture content greater than the equilibrium value, otherwise the briquettes may swell during storage and transportation and disintegrate when exposed to humid atmospheric conditions.

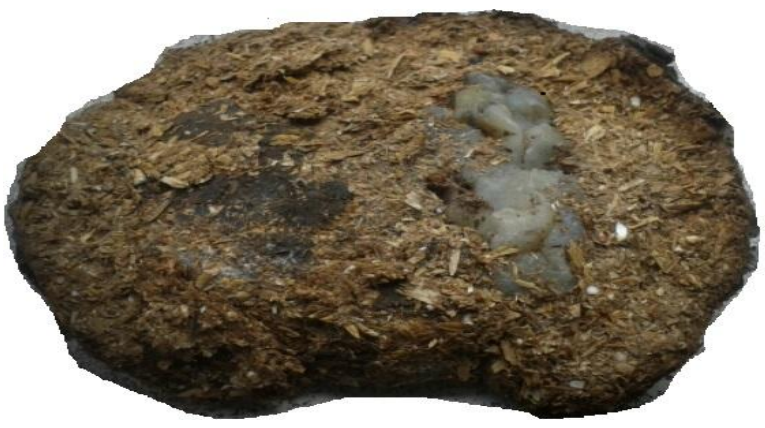

Figure 6: Image of the Waste Plastic-Biomass Briquette.

\section{ii. Effect of Temperature of Biomass}

By varying the temperature of biomass the briquette density, briquette crushing strength and moisture stability can be varied. In a screw extruder, the temperature does not remain constant in the axial direction of the press but gradually increases. Internal and external friction causes local heating and the material develops self-bonding properties at elevated temperatures. It can also be assumed that the moisture present in the material forms steam under high pressure conditions which then hydrolyses the hemicelluloses and lignin portions of biomass into lower molecular carbohydrates, lignin products, sugar polymers 
and other derivatives [6]. These products, when subjected Waste plastic-Biomass Briquetting were done in different to heat and pressure in the die, act as adhesive binders and proportions. The behaviour of the briquette significantly provide a bonding effect "in situ". The addition of heat changed as the amount of saw dust and waste plastic was also relaxes the inherent fibers in biomass and apparently increased. The compressive strength gradually went softens its structure, thereby reducing their resistance to upward due to the fact of binding by lignocelluloses saw briquetting which in turn results in decreased specific dust and waste plastic melt. power consumption and a corresponding increase in production rate and reduction in wear of the contact parts. In this case preheating of raw material is not employed and the die is not heated. In fact the die needs cooling for smooth briquetting.

\section{IV.RESULT AND ANALYSIS}

The briquettes were produced in a briquetting Thermal Piston press, using moderate compaction pressure. The briquettes were produced with dimensions of $75 \mathrm{~mm}$ diameter and $120 \mathrm{~mm}$ length and then were characterized by proximate chemical analysis, following ASTM procedures for moisture, volatile materials, and ash. All analyses were performed in triplicate. The samples were subjected to mechanical tests using an Emic Universal test machine, with a load speed of $1 \mathrm{~mm} / \mathrm{min}$. For mechanical tests three briquettes were used for each waste. The same briquettes samples were also used, previously, to determine the bulk density (relation between mass and volume of the briquettes). The high heating value (HHV) was determined using a bomb calorimeter. To evaluate the behaviour of the briquettes during burning processes they were subjected to combustion on a home grill.

Table I: Representing the Proximate Analysis result and Calorific Value of Individual raw material.

\begin{tabular}{|c|c|c|c|c|c|}
\hline \multirow[b]{2}{*}{$\overrightarrow{\underline{\Xi}}$} & \multicolumn{5}{|c|}{ Proximate Analysis Result } \\
\hline & 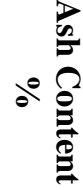 & 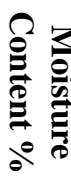 & 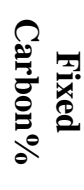 & 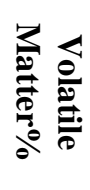 & 承 \\
\hline Dust & 1.37 & 8.25 & 1.49 & 88.89 & $6-10$ \\
\hline $\begin{array}{c}\text { Rice } \\
\text { Husk }\end{array}$ & 18.51 & 5.41 & 13.49 & 62.95 & $4-8$ \\
\hline $\begin{array}{l}\text { Mixed } \\
\text { Plastic }\end{array}$ & 4.59 & 1.37 & 1.14 & 92.90 & $35-45$ \\
\hline
\end{tabular}

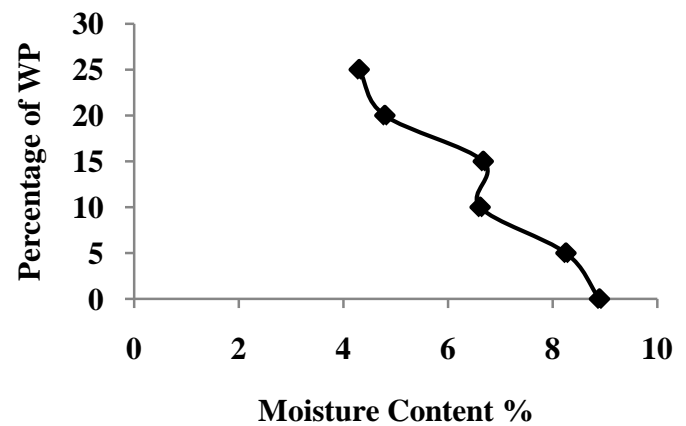

Figure 7: Showing the relation between Moisture content and Percentage Waste Plastic in Briquetting.
Table II: Showing the increase in Compressive strength and Calorific value with respect to percentage Waste Plastic Material to Biomasses.

\begin{tabular}{|c|c|c|c|c|c|}
\hline $\begin{array}{l}\text { SD\% + } \\
\text { RH\% + } \\
\text { RS\% + } \\
\text { WP\% }\end{array}$ & 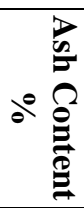 & 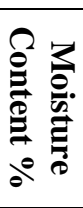 & 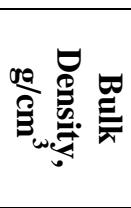 & 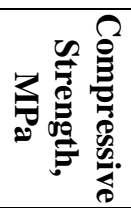 & 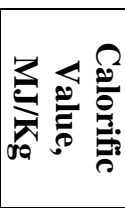 \\
\hline $\begin{array}{l}75 \%+ \\
10 \%+ \\
10 \%+ \\
0 \%\end{array}$ & 5.79 & 8.89 & 1.19 & 1.73 & 4.87 \\
\hline $\begin{array}{l}70 \%+ \\
15 \%+ \\
10 \%+ \\
5 \%\end{array}$ & 4.78 & 8.25 & 1.13 & 2.21 & 6.10 \\
\hline $\begin{array}{l}60 \%+ \\
20 \%+ \\
10 \%+ \\
10 \%\end{array}$ & 5.67 & 6.61 & 1.16 & 2.42 & 6.98 \\
\hline $\begin{array}{l}50 \%+ \\
25 \%+ \\
10 \%+ \\
15 \%\end{array}$ & 5.32 & 6.67 & 1.15 & 3.54 & 7.5 \\
\hline $\begin{array}{l}40 \%+ \\
30 \%+ \\
10 \%+ \\
20 \%\end{array}$ & 5.43 & 4.79 & 1.08 & 3.96 & 7.95 \\
\hline $\begin{array}{l}35 \%+ \\
30 \%+ \\
10 \%+ \\
25 \%\end{array}$ & 5.7 & 4.3 & 1.05 & 4.38 & 9.6 \\
\hline
\end{tabular}

Naturally plastics composed of hydro carbonados material. As a result of that it contributes to the briquette fuel value. The more the percentage of the waste plastic the more is the calorific value. Figure 9 shows the trend of fuel value augmentation.

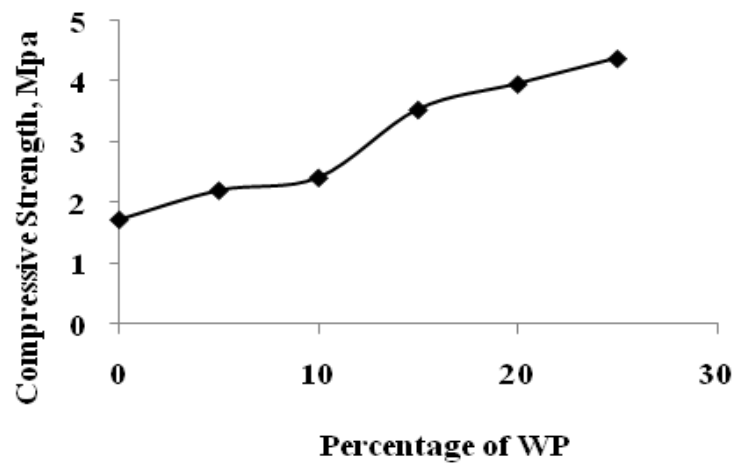

Figure 8: Compressive Strength as a function of WP percentage. 


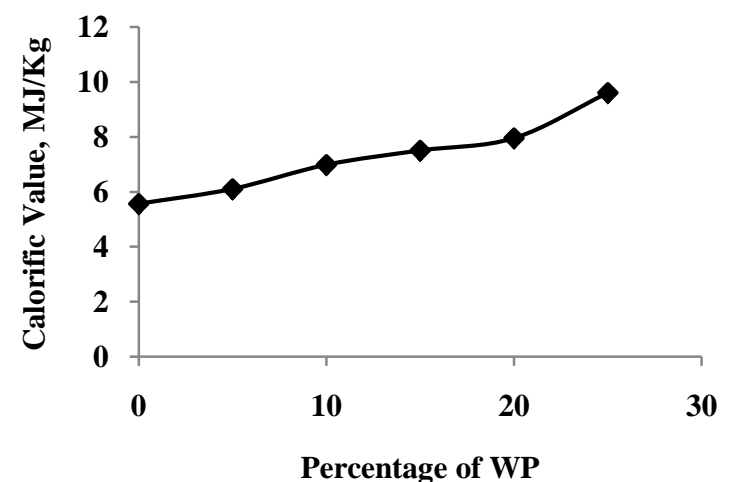

Figure 9: showing that the Calorific Value of WPBiomass Briquette Increases as WP added.

\section{CONCLUSION}

This investigation studied the optimum proportion of waste plastics to be added with biomass for a good quality of briquettes. It is found that 10 percent addition offers a good array of property improvement. Moreover this study demonstrates the feasibility of plastic incorporation with Biomass. However burning plastics is a big concern for air pollution. But non-degradable plastics create long term soil pollution. High temperature burning of plastics avoids incomplete combustion. Biomass-plastic Briquette can create higher temperature than Biomass briquette only. Therefore waste plastics are converted into resources. The extension of this study will be done to design commercial production and mitigate stack gas pollution considering scrubber.

\section{ACKNOWLEDGEMENT}

The Authors would like to thank the "Centre of Excellence", a Research centre of Shahjalal University of Science and Technology, SUST, Sylhet, Bangladesh for financing this work. In addition the authors also acknowledge the contribution of "Centre for Environmental and Process Engineering", CEP, SUST for the technical services.

\section{REFERENCES}

[1] www.petrobangla.org.bd/Petrobangla Annual Report 2014/ page 29-32.

[2] Chou, C. S., Yang, R. Y., Chen, J. H., \& Chou, S. W. (2010). The optimum conditions for preparing the lead-free piezoelectric ceramic of $\mathrm{Bi} 0.5 \mathrm{Na} 0.5 \mathrm{TiO} 3$ using the Taguchi method. Powder Technology, 199(3), 264-271.

[3] Chou, C. S., Lin, S. H., \& Lu, W. C. (2009). Preparation and characterization of solid biomass fuel made from rice straw and rice bran. Fuel processing technology, 90(7), 980-987.

[4] Mishra, S. K., Sreedhar, I., Iyer, P. V. R., \& Grover, P. D. (1995). 5. Effect OF Feed Preheating ON Briquetting OF Different Biomass. REGIONAL WOOD ENERGY DEVELOPMENT PROGRAMME IN ASIA GCP/RAS/154/NET, 31

[5] de Oliveira Maiaa, B. G., Souzab, O., Marangonib, C., Hotzaa, D., de Oliveiraa, A. P. N., \& Sellinb, N. (2014). Production and characterization of fuel briquettes from banana leaves waste. CHEMICAL ENGINEERING, 37.

[6] Li, Y., \& Liu, H. (2000). High-pressure densification of wood residues to form an upgraded fuel. Biomass and Bioenergy, 19(3), 177-186.
[7] Kathuria, R. S., \& Grover, S. (2012). Using agricultural residues as a biomass briquetting: an alternative source of energy.

[8] Islam, M. Serajul. "Prospects And Challenges Of Plastic Industries In Bangladesh." Journal of Chemical Engineering 26.1 (2012): 1621.

[9] Dr. Sadia Afroz Mukti Lecturer, Department Of Law, Dhaka International University, Dhaka, Bangladesh "Solid Waste Management In Dhaka City: Problems And Prospects"- ijird, November 2013

[10] Maninder et al Using Agricultural residues as a Biomass briquetting: An Alternative source of Energy IOSR page 11-15, 2012

[11] Ozair Souza et al Production and Characterization of Fuel Briquettes from Banana Leaves Waste Bianca G. de Oliveira Maia 2014, AIDIC Servizi S.r.1. DOI: 10.3303/CET1437074. 